\title{
Strict coupling between the development of Planktothrix rubescens and microcystin content in two nearby lakes south of the Alps (lakes Garda and Ledro)
}

\author{
Nico Salmaso $^{1 *}$, Adriano Boscaini ${ }^{1}$, Shiva Shams ${ }^{1,2}$ and Leonardo Cerasino ${ }^{1}$ \\ 1 IASMA Research and Innovation Centre, Istituto Agrario di S. Michele all'Adige - Fondazione E. Mach, Via E. Mach 1, \\ 38010 S. Michele all'Adige, Trento, Italy \\ ${ }^{2}$ Human and Environmental Toxicology Group, Department of Biology, University of Konstanz, P.O. Box X-918, D-78457, \\ Konstanz, Germany
}

Received 15 July 2013; Accepted 10 September 2013

\begin{abstract}
Cyanobacteria and their principal cyanotoxins were studied in the largest Italian lake (Lake Garda, $65 \mathrm{~m}$ a.s.1.) and in a near smaller reservoir (Lake Ledro, $652 \mathrm{~m}$ a.s.1.). The two lakes share a fraction of water due to a pipe pumping water from and into the lakes and the same dominant cyanobacterial species (Planktothrix rubescens). Despite the differences in the concentrations of cyanotoxins (mostly microcystins, MCs) and biovolumes of $P$. rubescens $\left(\mathrm{BV}_{\mathrm{Pr}}\right)$ (over one order of magnitude), the Bayesian analyses linking these two variables showed striking similarities, suggesting the existence of similar toxic genotypes colonizing the two water bodies and a constitutive MC production. It was stressed that a greater sensitivity and reliability in the management strategies aimed at minimizing the risks due to cyanobacteria should also contemplate the use of specific lake-tailored models linking $\mathrm{MCs}$ and $\mathrm{BV}_{\mathrm{Pr}}$.
\end{abstract}

Key words: Cyanobacteria / Planktothrix rubescens / microcystins / risk assessment / Bayesian analysis

\section{Introduction}

Cyanobacteria are a group of photosynthetic bacteria which have successfully colonized almost every type of terrestrial and aquatic environments, from hot thermal ecosystems, to the cold polar environments (de los Ríos, 2004; Metcalf et al., 2012). Species of this group of phytoplankters are particularly abundant in eutrophic and thermally stable lakes, where they can form huge water blooms with detrimental effects for ecosystem functionality and water exploitation (Paerl, 2008; Peretyatko et al., 2010). These effects are further exacerbated when blooms are caused by populations producing secondary toxic metabolites (cyanotoxins) (Azevedo et al., 2002; Valério et al., 2008; Bogialli et al., 2013). Of these, the most important include several mostly hepatotoxic (microcystins (MCs), nodularins and cylindrospermopsins) and neurotoxic (anatoxin-a, anatoxin-a(S) and saxitoxins) compounds (Meriluoto and Codd, 2005; Sedmak et al., 2008).

\footnotetext{
*Corresponding author: nico.salmaso@fmach.it
}

By far, the group of $\mathrm{MCs}$, with over 80 variants, represents one of the most widespread algal toxins, with many examples of toxic blooms and lethal intoxications reported all over the world (Hudnell, 2008). MCs are heptapeptides of low molecular weight. The most important planktonic producers are represented by Planktothrix spp., Microcystis spp. and Anabaena spp. MCs share the common structure cyclo(D-Ala ${ }^{(1)}-\mathrm{X}^{(2)}-\mathrm{D}-\mathrm{MeAsp}^{(3)}-\mathrm{Z}^{(4)}$ - Adda $^{(5)}-\mathrm{D}-\mathrm{Glu}^{(6)}-\mathrm{Mdha}^{(7)}$ ) in which $\mathrm{X}$ and $\mathrm{Z}$ are sites of amino acid substitutions at positions 2 and 4 of the peptide ring (Metcalf and Codd, 2012). For example, microcystin-RR has two L-arginine at the two variable amino acid positions. Signs of acute intoxication by MCs include the deformation of the cytoskeleton in the hepatocytes and liver degeneration (Humpage, 2008). Owing also to the difficulties in conducting epidemiological studies, the long-term effects of MCs have been less studied. Nevertheless, a few investigations carried out in China (Yu, 1989; Ueno et al., 1996; Zhou et al., 2002), USA (Fleming et al., 2002) and Serbia (Svircev et al., 2009), suggest a link between MCs exposure and human cancer incidence, mostly through the consumption of drinking water. 
The identification of the factors controlling the development of MCs begun to be correctly understood only recently. In freshwater ecosystems, MCs are present with values from below $1 \mu \mathrm{g} . \mathrm{L}^{-1}$ up to over $30000 \mu \mathrm{g} . \mathrm{L}^{-1}$ (Sivonen and Jones, 1999; Kardinaal and Visser, 2005; Naselli-Flores et al., 2007). A large part of this variability is due to differences in the development of cyanobacterial biomasses and to the presence in the populations of toxic and/or non-toxic genotypes (Sivonen and Börner, 2008). Physiological variations controlled by environmental factors (e.g., light, iron and $\mathrm{pH}$; Neilan et al., 2012) contribute to the fine-tuning of the toxin in the cells. More specifically, the existence of both toxic and non toxic strains can explain the reasons why blooms caused by the same species can have different levels of toxicity.

These above considerations have important implications for the correct management of potentially toxic blooms, requiring an in depth knowledge of cyanobacteria both at the species and population level. Planktothrix rubescens (De Candolle ex Gomont) Anagnostidis and Komárek is the most typical and abundant cyanobacterium in many deep Italian lakes (Messineo et al., 2006; D'Alelio et al., 2011; Salmaso et al., 2012a, 2012b) and in many Italian reservoirs (Naselli-Flores et al., 2007). In this paper, we report the results of a study carried out in two populations of $P$. rubescens in two nearby subalpine lakes in Northeastern Italy, namely lakes Garda (a natural large and deep lake) and Ledro (a natural lake with artificial water regulation for hydroelectric purpose). These two lakes are connected by a water pumping system, which favours an exchange of microalgae.

Our hypothesis is that the two lakes, after several years of hydraulic interchange and natural and/or anthropogenic dispersal, developed populations of Planktothrix with similar toxic potential, irrespective of the differences in the physiographic characteristics and trophic state. This hypothesis can be quantitatively tested evaluating the MCs cell quota of the two populations, inferred from statistical models relating MCs and biovolumes of P. rubescens $\left(\mathrm{BV}_{\mathrm{Pr}}\right)$. The specific objectives include (i) the definition of statistical models relating the biomass of Planktothrix and MCs in the two lakes, and (ii) the degree of comparability of the models in the two lakes and in two different layers characterized by different environmental conditions (surface and metalimnion). Finally, the implications of the results for the management and mitigation of the effects of blooms for human health and water exploitation will be briefly discussed. The models will be evaluated using Bayesian analyses. Bayesian inference is an important statistical method, which is increasingly being used in ecological investigations (Ellison, 2004; Hobbs and Hilborn, 2006). This approach has many advantages in the interpretation of the model parameters and its adoption in ecological studies has been strongly encouraged (McCarthy, 2007). In this work, the use of a Bayesian approach allowed us to make direct probability statements about MC cell quota using its posterior distribution. Examples of applications in ecology are reported and discussed in McCarthy (2007) and Kéry (2010).

\section{Material and Methods}

\section{Study sites}

Lakes Garda and Ledro are located at the southern border of the Northeastern Italian Alps, at $65 \mathrm{~m}$ and 652 $\mathrm{m}$ a.s.l., respectively (Fig. 1). Lake Garda is the largest Italian lake with a volume of more than $49 \times 10^{9} \mathrm{~m}^{3}$, a maximum depth of $350 \mathrm{~m}$ and a surface of $368 \mathrm{~km}^{2}$. Compared with the other deep lakes in northern Italy, Lake Garda has a long renewal time, of more than 27 years. Lake Ledro was originally a natural basin. Since 1928 it has undergone a strong hydrological modifications and widening, and at present it is used for the production of hydroelectric power. Volume, maximum depth and surface are $76 \times 10^{6} \mathrm{~m}^{3}, 48 \mathrm{~m}$ and $2.1 \mathrm{~km}^{2}$, whereas the renewal time is lower than 1 year. Lake Ledro is connected by a penstock to a pumped-storage plant on the shores of Lake Garda (Ponale), from which water may be again pumped to Lake Ledro. The two lakes host populations of $P$. rubescens, which represents the dominant cyanobacterium in both basins (Salmaso et al., 2012a). In Lake Ledro, this species was the cause of many recent red water blooms (2009-2010).

\section{Sampling and analytical methods}

In both lakes, the sampling stations were located at the deepest point of the basins (Fig. 1). In Lake Garda, the sampling station was included in the Long-Term Ecological Research (LTER) network since 2006 (http:// www.lteritalia.it/). Field and laboratory measurements were made between January 2009 and December 2011 (Garda), and June 2011 and December 2012 (Ledro) by the same team and with the same equipments and standard methods. The data refer to samples collected at a monthly frequency at the surface (between 0 and $2 \mathrm{~m}$ ) and around the metalimnetic layers (19-20 $\mathrm{m}$ and $20 \mathrm{~m}$ in lakes Garda and Ledro, respectively). In the largest lake, previous investigations clearly showed that the seasonal development of cyanobacteria in the deepest station was very similar to that recorded in other zones of the lake, e.g., the southeast basin (Fig. 1; Salmaso, 2002). In Lake Ledro, occasional vertical and horizontal profiles obtained using submersible spectrofluorometers (FluoroProbe) demonstrated a comparable distribution of Planktothrix in the pelagic zone (unpublished data).

Vertical profiles of water temperature were carried out with a multiparameter probe (Idronaut Ocean Seven 316). Secchi disk readings were carried out with the aid of a bathyscope, whereas the light attenuation coefficients were measured with a submersible irradiance sensor, LiCor 192SA. Determination of algal nutrients (Total Phosphorus - TP, Soluble Reactive Phosphorus - SRP and Nitrates - $\mathrm{NO}_{3}-\mathrm{N}$ ) was carried out following the standard methods (APHA et al., 2000). Phytoplankton counting was carried out with inverted microscopes on samples fixed with Lugol's solution. To increase reliability in abundance determinations, Planktothrix cells - along 


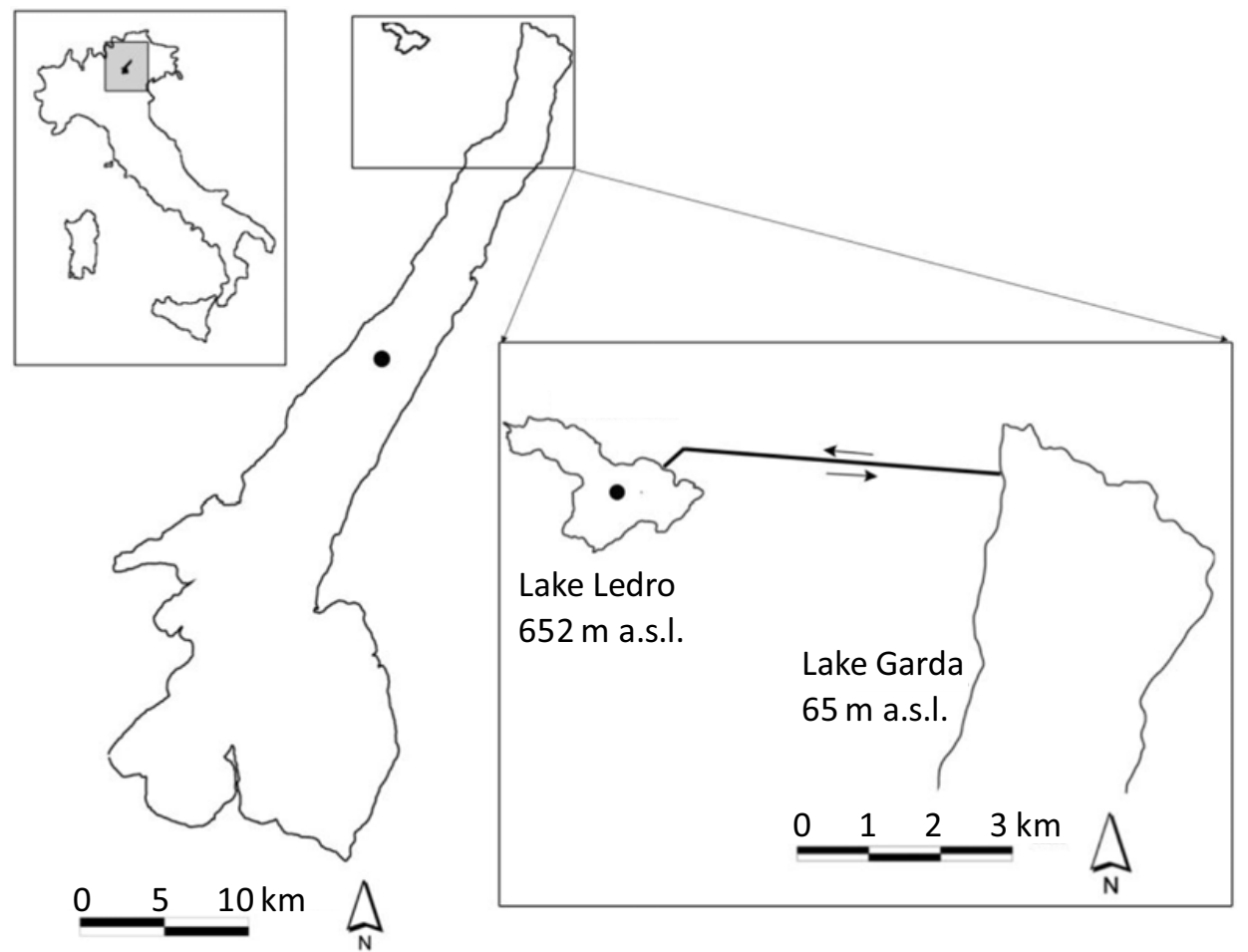

Fig. 1. Location of lakes Garda and Ledro. The black circles indicate the sampling stations. The two lakes are connected by a penstock pumping water from and into the lakes.

with other larger organisms (see Rott et al., 2007) - were estimated examining five transects at 200 magnification (i.e., ca. $25 \%$ of the bottom of a $10 \mathrm{~mL}$ sedimenting chamber). Biovolumes were calculated from recorded abundances and specific biovolumes approximated to simple geometric solids (Rott et al., 2007). MCs were determined by LC-MS/MS (Waters Acquity UPLC ${ }^{\mathbb{R}}$ directly coupled to an AB Sciex 4000 QTRAP hybrid triple quadrupole-linear ion trap mass spectrometer). The analyses followed the methods described in Guzzella et al. (2010) and Cerasino and Salmaso (2012).

\section{Data analysis}

Bayesian analyses were computed using WinBUGS (Lunn et al., 2000), and the packages MCMCpack (Martin et al., 2011) and R2WinBUGS (Sturtz et al., 2005) in R 3.0.1 ( $\mathrm{R}$ Core Team, 2013). The Bayesian approach allows obtaining a posterior distribution of the parameters (e.g., regression slopes) given the data and existing knowledge (priors) for these parameters (McCarthy and Masters, 2005; McCarthy, 2007). With a Bayesian approach, every parameter has an entire distribution (posterior) which can be represented as a graph (e.g., using histograms, like in Figs. 3 and 4). The central tendency of a parameter can be estimated computing the mean (or median and mode), while the standard deviation of the distribution can be used as a measure of the uncertainty in the estimate (Kéry, 2010). In addition, a credible interval (CRI, the analog of a confidence interval) is any region of the distribution containing $95 \%$ of the area under the curve. In this work, we will consider 95\% CRIs delimited by the 2.5 and the 97.5 percentile points of the posterior sample of a parameter (see Table 1; Kéry, 2010). This represents a clear advantage, because allows to directly compute the probability that a parameter has a particular value rather than the probability to obtain a particular type of data given some null hypothesis (Kéry, 2010). The posterior distributions were obtained with the computation of Markov chain Monte Carlo (MCMC), which is the method commonly used to fit models using a Bayesian approach (Martin et al., 2011). For each analysis, a Markov chain of length 11000 was estimated, discarding the first 1000 points as a burn-in. Before summarizing the parameters, Markov chains were visually inspected for convergence and stationarity. Uninformative, flat default priors were used for the coefficient parameters. This way, the posterior distribution is mostly controlled by the observed data, giving numerically very similar results as the classical statistical approach (frequentist mode of inference). Comparability of slopes and intercepts (the two depths in each lake, or the two lakes as factors) in different models ( $c f$. Figs. 3 and 4) was tested with the Bayes factors tool in the MCMCpack (Martin et al., 2011). In each run, three models were tested, including a unique intercept and slope, different intercepts and a common slope, and different intercepts and slopes. Bayes factors values greater than 1, 3, 20 and 150 indicate barely positive, positive, strong and very strong evidence, respectively, against an alternative model (Kass and Raftery, 1995). 
Table 1. Linear relationships between $\mathrm{MCs}$ and the biovolume of P. rubescens $\left(\mathrm{BV}_{\mathrm{Pr}}\right)$. Parameter model estimation refers to lakes (a) Garda and (b) Ledro and (c) to the two lakes (pooled data). Lower and Upper indicate central 95\% Bayesian CRIs, delimited by the 2.5 and the 97.5 percentile points of the posterior samples of a and b (Figs. 3(c), (d) and 4(b)). Slopes b are an estimate of the cell quota $\left(\mu \mathrm{g} \cdot \mathrm{mm}^{-3}=\mathrm{fg} \cdot \mu \mathrm{m}^{-3}\right)$.

\begin{tabular}{|c|c|c|c|c|c|}
\hline & & Mean & St. Dev. & Lower & Upper \\
\hline \multirow[t]{2}{*}{ (a) } & Intercept, $a$ & -9.701 & 13.21 & -35.56 & 15.99 \\
\hline & $\mathrm{MCs}, b$ & 0.528 & 0.069 & 0.393 & 0.664 \\
\hline \multirow[t]{2}{*}{ (b) } & Intercept, $a$ & -31.3 & 135 & -294 & 237 \\
\hline & $\mathrm{MCs}, b$ & 0.511 & 0.047 & 0.416 & 0.604 \\
\hline \multirow[t]{2}{*}{ (c) } & Intercept, $a$ & -11.03 & 27.15 & -63.95 & 42.13 \\
\hline & MCs, $b$ & 0.506 & 0.018 & 0.469 & 0.541 \\
\hline
\end{tabular}

Bayesian analyses were compared with the results obtained using the frequentist mode of inference. The comparability of slopes and intercepts in the regression models was tested by an analysis of covariance (ANCOVA). Regression models were selected based on the Akaike information criterion (AIC) and ANOVA tests (R Core Team, 2013). Only the biovolume of Planktothrix and MCs values greater than the detection/ quantification limits ( $c f$. Akcaalan et al., 2006) were included in the analyses $\left(c a .0 .2 \mathrm{~mm}^{3} \cdot \mathrm{m}^{-3}\right.$, five cells in five transects; and $0.5 \mathrm{ng} . \mathrm{L}^{-1}$, respectively).

\section{Results}

\section{Environmental variables}

The two lakes showed a marked stratification from May-June to September-October. Water temperatures in Lake Garda ranged between 8.2 and $23.6^{\circ} \mathrm{C}(0-2 \mathrm{~m})$, and 8.2 and $19.9^{\circ} \mathrm{C}(19-20)$, whereas the maximum deepening of the metalimnetic layer was observed down to $30-40 \mathrm{~m}$. Maximum differences of temperature in the two layers during maximum summer stratification (June-August) were around $2.9-8.4^{\circ} \mathrm{C}$. In Lake Ledro, water temperatures had a large range of variation, about $3.3-23.2^{\circ} \mathrm{C}$ $(0 \mathrm{~m})$ and $3.4-7.1^{\circ} \mathrm{C}(20 \mathrm{~m})$, with a deepening of the metalimnetic layer down to $15-25 \mathrm{~m}$, and differences of temperature between the surface and $20 \mathrm{~m}$ around $2.6-17.8^{\circ} \mathrm{C}$ in June and August.

During the maximum stratification period (June-August), the euphotic depths in lakes Garda and Ledro were between 15 and $20 \mathrm{~m}$, and 16 and $19 \mathrm{~m}$, respectively. Overall, Secchi disk depth transparencies and chlorophyll-a were about 3-19 $\mathrm{m}$ and $0.7-8.3 \mu \mathrm{g} . \mathrm{L}^{-1}$ (Garda), and 2.3-11.3 $\mathrm{m}$ and 0.9-34.2 $\mu$ g. $\mathrm{L}^{-1}$ (Ledro).

In Lake Garda, TP concentrations ranged about 5-16 $\mu \mathrm{g} . \mathrm{L}^{-1}(0-2 \mathrm{~m})$ and 4-35 $\mu \mathrm{g} . \mathrm{L}^{-1}(19-21 \mathrm{~m})$. Corresponding values in Lake Ledro were 2.5-21 and 9-35 $\mu \mathrm{g} . \mathrm{L}^{-1}$. Average concentrations (surface and $20 \mathrm{~m}$ ) were $11 \mu \mathrm{g} . \mathrm{L}^{-1}$ (Garda) and $14 \mu \mathrm{g} . \mathrm{L}^{-1}$ (Ledro).

\section{Planktothrix and MCs temporal dynamics}

In both lakes, $P$. rubescens showed its maximum development in the metalimnetic layers during the stratification months, between July and November (Garda) and June-July and September (Ledro) (Figs. 2(a) and (b)). The maximum biomass values of Planktothrix in Lake Ledro were around one order of magnitude greater than the values observed in Lake Garda (Figs. 2(a) and (b)).

Planktothrix was the dominant cyanobacterium in the two lakes. In Lake Garda, the maximum and mean biovolume values of $P$. rubescens at 0-2 and 19-21 m (715 and $116 \mathrm{~mm}^{3} \cdot \mathrm{m}^{-3}$ ) almost coincided with the corresponding values computed for the whole cyanobacteria group (726 and $134 \mathrm{~mm}^{3} \cdot \mathrm{m}^{-3}$ ). The less abundant cyanobacterial species in Lake Garda were mostly represented by Snowella cf. aracnoidea, Dolichospermum lemmermannii and Aphanothece/Aphanocapsa species. Similarly, in Lake Ledro, $P$. rubescens was by far the most abundant cyanobacterium. Maximum and mean biovolume values at 0 and $20 \mathrm{~m}$ of Planktothrix and total cyanobacteria were $8069-1619 \mathrm{~mm}^{3} \cdot \mathrm{m}^{-3}$ and $8070-1623 \mathrm{~mm}^{3} \cdot \mathrm{m}^{-3}$, respectively. The other cyanobacterial species in this lake were represented by very low biomasses of Chroococcus sp. and Pseudanabaena spp.

MCs showed a strict connection with the development of Planktothrix (see the next section) (Figs. 2(c) and (d)). As in the case of Planktothrix biovolumes, the values of MCs in Lake Ledro were around one order of magnitude greater than the values measured in Lake Garda. The more abundant chemical variants $(>90 \%)$ in the two lakes were the desmethyl-RR (Garda and Ledro) and desmethyl-LR (mostly Ledro). Other very minor variants in the two lakes included MCs YR, RR and LR.

\section{MCs - Planktothrix biovolume models}

The results of the regression analyses between MCs and the biovolumes of Planktothrix are reported in Table 1 and Fig. 3. In each lake, the models were almost coincident considering separately the two layers $(0 \mathrm{~m}$ and $20 \mathrm{~m})$. In Lake Garda, the comparison by Bayes Factor (Martin et al., 2011) of the regression model with a common slope and intercept, versus models with different intercepts and intercepts/slopes showed that there was barely positive and positive evidence to support the simpler model (Bayes factors, 1.02 and 3.9, respectively) (Fig. 3a). Similar results were verified in Lake Ledro (Bayes factors, 1.00 and 24.2, 

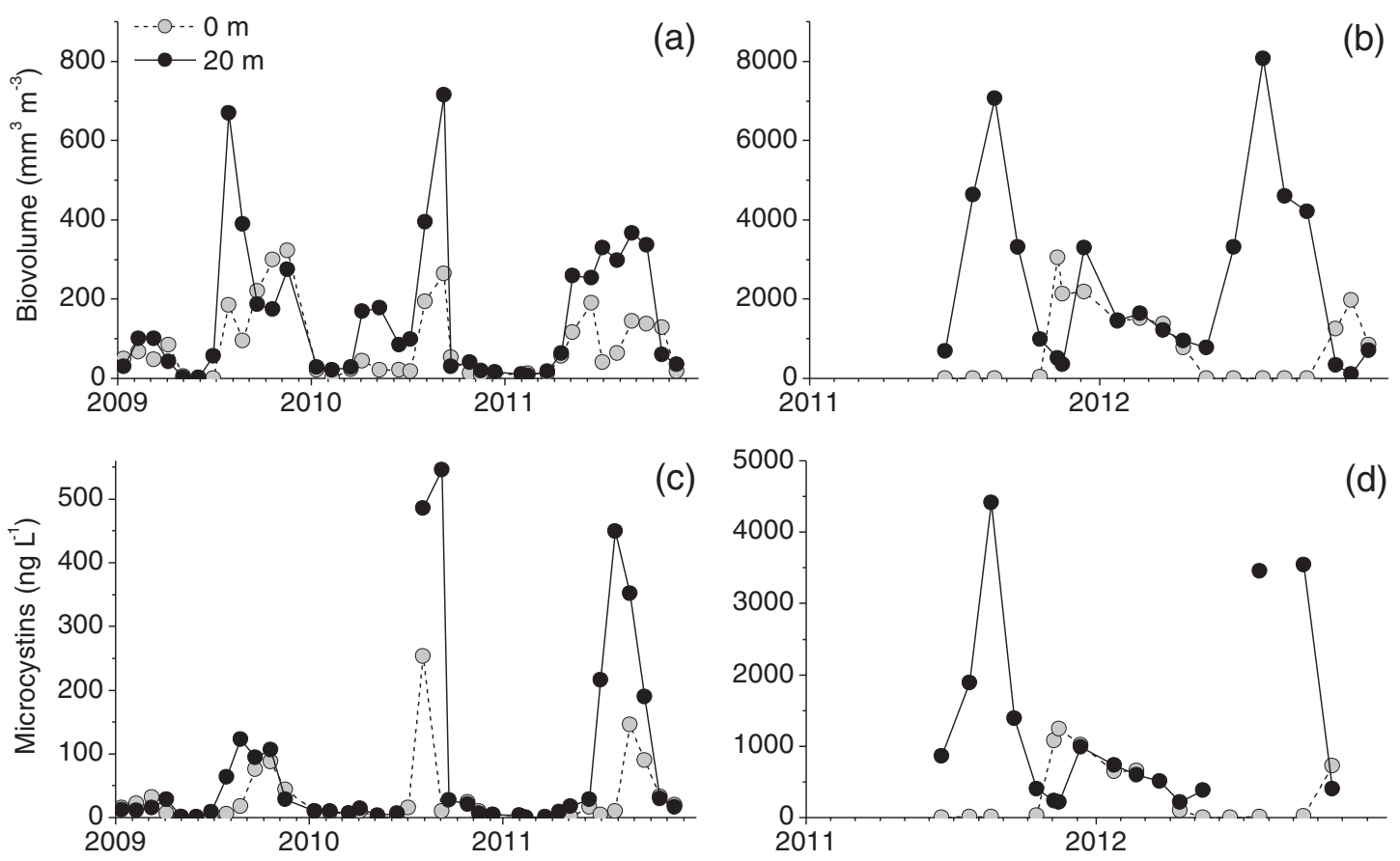

Fig. 2. Temporal development of biovolumes of P. rubescens (upper panels) and MCs (lower panels) in lakes (a, c) Garda and $(b, d)$ Ledro.

respectively) (Fig. 3b). In both lakes, after ANCOVA computation, the selection of the more simple model $(P<0.001)$ compared with the two alternative models $(P>0.10)$ was confirmed by the ANOVA analyses and AIC values. The models $\left(\mathrm{MC}=a+b \times \mathrm{BV}_{\mathrm{Pr}}\right)$ for the two lakes were $($ Table 1$): \mathrm{MC}=-9.7+0.53 \times \mathrm{BV}_{\operatorname{Pr}}($ Lake Garda $)$ and $\mathrm{MC}=-31.3+0.51 \times \mathrm{BV}_{\operatorname{Pr}}$ (Lake Ledro), where $\mathrm{MC}$ is the total microcystins, and $\mathrm{BV}_{\mathrm{Pr}}$ the biovolume of $P$. rubescens. The parameters $a$ and $b$ were equivalent to those estimated by the frequentist mode of inference ( -9.8 and 0.53 , and -33.6 and 0.51 for the lakes Garda and Ledro, respectively; both relationships, $P<0.001$ ).

Despite the minor range of $\mathrm{MCs}$ and $\mathrm{BV}_{\mathrm{Pr}}$ values in Lake Garda, the slopes $b$ in the two lakes were almost coincident. Nevertheless, the $95 \%$ CRIs of the parameters $b$ showed a wider range in Lake Garda (0.39-0.66) compared with Lake Ledro (0.42-0.60) (Table 1 and Figs. 3(c) and (d)). Considering the whole dataset (the two lakes), the comparison of alternative models with a common slope and intercept, versus models with different intercepts and intercepts/slopes showed that there was positive evidence to support a model with a common slope and intercept (Bayes factor, 1 and 21.6). The model for the whole dataset (Fig. 4(a), thick line; Table 1) was: $\mathrm{MC}=-11.0+0.51 \times \mathrm{BV}_{\mathrm{Pr}}$. Even in this case, the selection of the more simple model $(P<0.001)$ compared with the two alternative models $(P>0.10)$ was confirmed by the AIC values and ANOVA analyses.

\section{Discussion}

The hypothesis that the two lakes developed populations of $P$. rubescens with similar toxic potential was fully confirmed by the results of this work. The concentrations of MCs were linked to the biovolumes of Planktothrix, with the same mean cell quota $\left(0.51-0.53 \mu \mathrm{g} \cdot \mathrm{mm}^{-3}\right)$, irrespective of the position of the samples (surface or metalimnion) and differences in the two lakes (physiography, trophic status). The greater variability in the estimation of the slopes $b$ in Lake Garda was also probably due to a higher uncertainty in the estimation of biovolumes and MCs at the lower end of the measurement scales (Fig. 3). A further fraction of unexplained variability was due to the control of cell quota by environmental and physiological factors, as well as changes in the proportion of toxic genotypes (Yéprémian et al., 2007). Nevertheless, considering the strict link between MCs and $\mathrm{BV}_{\mathrm{Pr}}$, these factors appeared of minor importance (see below). The control of MC concentrations was apparently linked to the same environmental factors controlling the development of Planktothrix.

$P$. rubescens is a very well-known cyanobacterium which develops in many deep lakes north and south of the Alps. Besides Lake Garda and the deep lakes south of the Alps (Buzzi, 2002; Morabito et al., 2002; Salmaso, 2002, 2011; Salmaso et al., 2012a), the environmental factors controlling the development of this cyanobacterium were extensively studied in other large subalpine lakes (Anneville et al., 2005; Jacquet et al., 2005; Gallina et al., 2011, 2013; Dokulil and Teubner, 2012), as well as in smaller, deep lakes (Nürnberg et al., 2003; Carraro et al., 2012) and reservoirs (Naselli-Flores and Barone, 2000; Almodóvar et al., 2004; Paulino et al., 2009). The increase of $P$. rubescens during the summer months is partly due to its ability to form strong thickening in the metalimnetic layers provided that the light intensity is not below the 
(a)

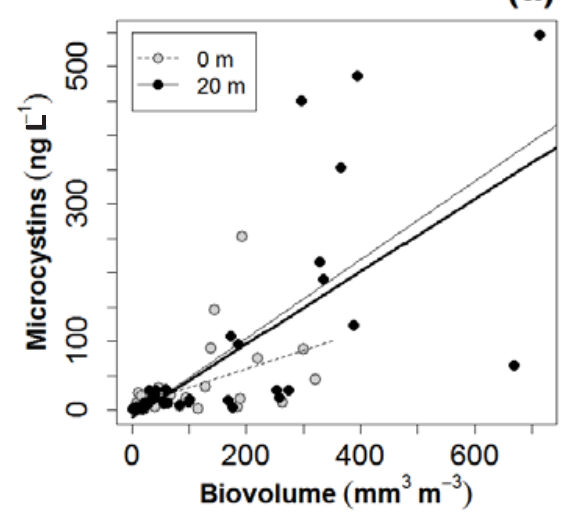

(c)

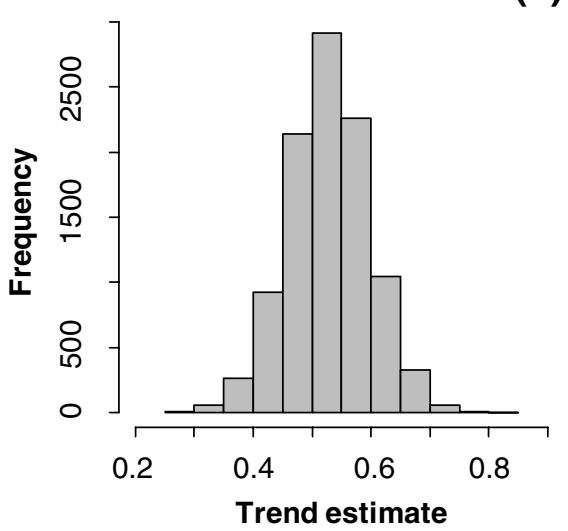

(b)

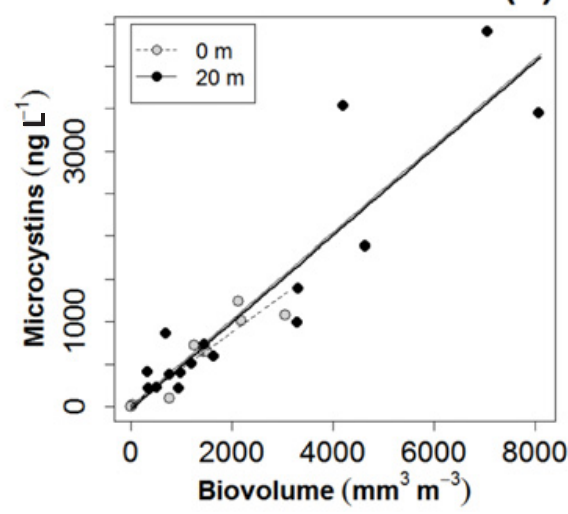

(d)

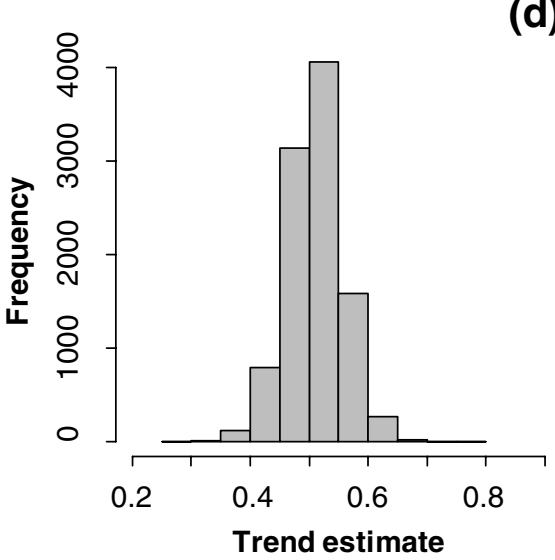

Fig. 3. Relationships between microcystins and biovolumes of P. rubescens in lakes (a) Garda and (b) Ledro. Predicted MCs values for the whole dataset are reported as thick solid lines. Thin solid and dashed lines refer to models computed for the data recorded at 0 and $20 \mathrm{~m}$, respectively. Panels (c) (Garda) and (d) (Ledro) report the posterior distribution of the slopes $b$ in the two models (length of the Markov chain $=10000)$. Note the different scales of the $x$ - and $y$-axis in $(a-b)$.

compensation point (Walsby and Schanz, 2002). The control of the vertical position is associated with the action of gas vesicles, cellular structures providing positive buoyancy (D'Alelio et al., 2011). The higher development observed at $20 \mathrm{~m}$ in lakes Garda and Ledro is consistent with many other observations which showed that the optimal depth for $P$. rubescens was located around the lower limit of the euphotic zone. Actually, the net production in Planktothrix was estimated to be active until about 3-4 $\mu \mathrm{mol} . \mathrm{m}^{-2} . \mathrm{s}^{-1}$, which are included in the lower range of Photosyntethically Active Radiation (PAR) intensities, generally measured at the $1 \%$ irradiance boundary (2-20 $\left.\mu \mathrm{mol} . \mathrm{m}^{-2} . \mathrm{s}^{-1}\right)$ (Reynolds, 2006).

The models linking the MCs concentrations and the biovolumes of Planktothrix at the surface and at $20 \mathrm{~m}$ did not differ greatly, suggesting a constitutive microcystin production relatively independent from environmental factors. This is consistent with the results obtained from both physiological and genetic investigations. In an experiment with batch cultures of Microcystis aeruginosa, Lyck (2004) showed a parallel development in the cell quotas of MC, protein, chlorophyll-a and carbohydrate; moreover, MCs were produced at rates approximating those needed to replace losses to daughter cells during division. Overall, the results indicated that MCs were constitutively expressed metabolites. Kardinaal and Visser (2005) concluded that the 2- to 3-fold physiological variation in laboratory culture cannot account for the MCs variability over one or more orders of magnitude that are usually observed in the field, indicating how the major source of variation could be related to the selection of toxic and non-toxic genotypes in different cyanobacterial species. Actually, a few recent studies regarding two among the more important producers of MCs Microcystis aeruginosa and $P$. rubescens - showed that differences in the MC content per cell in different water bodies depended from the presence of specific genotypes. Okello et al. (2010) found that the proportion of the mcyB genotype differed significantly between various Microcystis-dominated freshwater lakes in East Africa, and that the average MC content per cell depended linearly on the mcyB genotype proportion. Kurmayer et al. (2011) showed that the temporal changes in toxin production by populations of Planktothrix spp. were due to changes in the abundances of toxic and non-toxic genotypes. Similarly, studies carried out on Planktothrix 

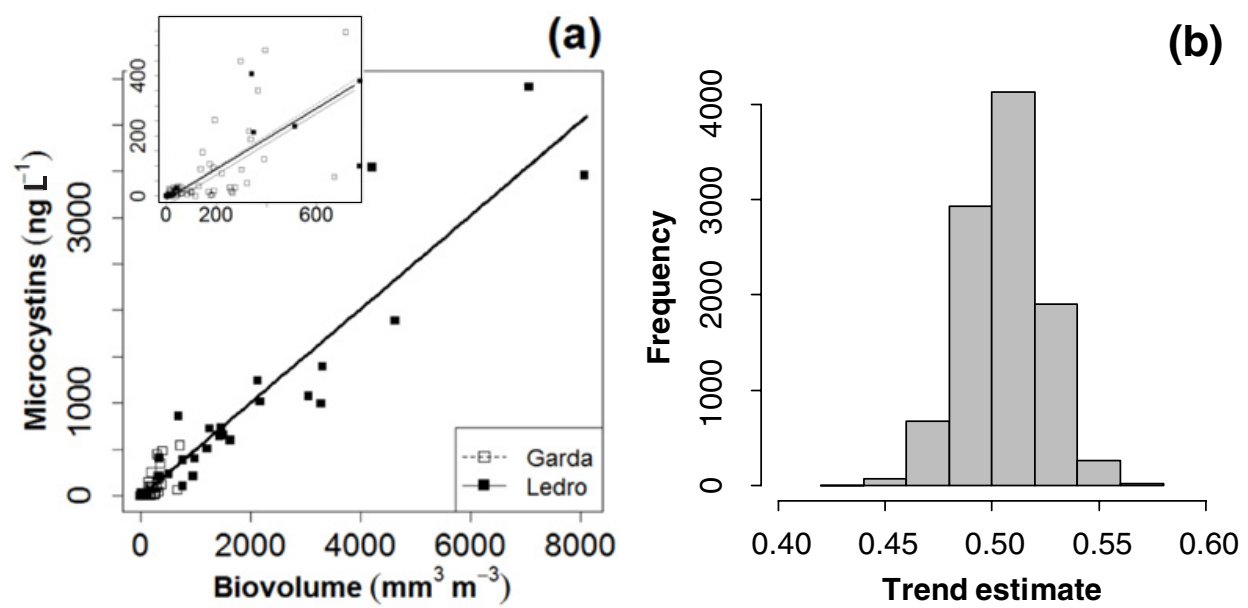

Fig. 4. (a) Relationship between microcystins and biovolumes of P. rubescens in lakes Garda and Ledro. Thin solid and dashed lines refer to the models computed for the data recorded in lakes Garda and Ledro, respectively (Figs. 3(a) and (b), respectively). Predicted MCs values for the whole dataset are reported as a thick solid line. The inset shows the graphical representation of the data of the two lakes limited to the $x$ - and $y$-ranges of Lake Garda. Panel (b) shows the posterior distribution of the model slope $b$ (length of the Markov chain $=10000)$.

agardhii clearly demonstrated that strong differences in MC cell quota can be present also in single water bodies. Yéprémian et al. (2007) interpreted the weak relationship between the biomass of $P$. agardhii and the MC concentrations in a small eutrophic lake as mainly caused by seasonal changes in the proportion of MC producing strains, the physiological state of cells and MC chemotypes diversity.

Though with differences in the range of concentrations of both MCs and $\mathrm{BV}_{\mathrm{Pr}}$ of one order of magnitude, the models linking these two variables in lakes Garda and Ledro showed striking similarities, suggesting the existence of two similar strains inhabiting the two water bodies. It was demonstrated that the geographical isolation could favour the development of different $\mathrm{MC}$ genotypes among populations of $P$. rubescens and $P$. agardhii (Kurmayer and Gumperberger, 2006). In our study, the interchange of water between the two adjacent lakes appears to represent an important factor for the exchange of homogeneous genetic strains. In addition, other natural and anthropogenic factors could have effectively favoured the exchange of different phytoplankton and cyanobacteria populations between the two lakes (Kristiansen, 1996; Nehring, 1998). In fact, we cannot exclude a priori the occurrence of damages and cell lysis in populations of Planktothrix passing through the pumping systems connecting the two water bodies.

The efficacy of the Bayesian approach in evaluating the reliability of regression models was apparent in the estimation of the distributional trend of the slopes relating the Planktothrix biomasses and MCs. In Lake Garda, the 95\% CRI had a wider range compared with the model computed in Lake Ledro (0.14 versus 0.09). Actually, both the biomass of Planktothrix $\left(<800 \mathrm{~mm}^{3} \cdot \mathrm{m}^{-3}\right)$ and the MCs concentrations $\left(<0.6 \mu \mathrm{g} . \mathrm{L}^{-1}\right)$ measured in Lake Garda were in the lower range of measurements usually documented in cyanobacterial populations (Sivonen and Jones, 1999; Naselli-Flores et al., 2007), and at the border of the provisional value $\left(1 \mu \mathrm{g} . \mathrm{L}^{-1}\right.$ for MC-LR $)$ at present provided by WHO (2008) as the guideline for cyanotoxins that are of health significance in drinking-waters (see Dietrich and Hoeger, 2005). The reference value used for MCs in drinking waters adopted by the Italian local authorities is the provisional WHO guideline, whereas bathing is prohibited when MCs concentrations exceed the value of $25 \mu \mathrm{g} . \mathrm{L}^{-1}$ (Chorus, 2012). Therefore, especially in the case of Lake Garda, the estimated models and parameters should be interpreted with care. The highest slopes in the Bayesian analyses (e.g., the upper 95\% CRIs) could be considered in the evaluation of MCs in the worst case scenarios.

The increasing evidence suggesting that MCs are constitutively expressed metabolites have important implications for water management and risk assessment. The only way to reduce MCs in these lakes is to control the growth of Planktothrix, because low values of biovolumes guarantee a low production of toxins. Furthermore, to evaluate the risks for human health associated with the contamination of waters used for bathing and drinking purposes, many countries are utilizing, for a rapid assessment of toxin contamination, different proxies including water transparency, algal chlorophyll and cyanobacterial abundance (biomass and/or densities) (Chorus, 2012). The independence of MCs cellular content in relation with the sampled depth in specific water bodies, and the strong correspondence of models relating MCs and Planktothrix biomasses in nearby lakes, represent further elements in favour of the adoption of more specific approaches to cyanotoxins risk assessment and management. However, taking into account the different capacity of toxin producing populations within the same species (Yéprémian et al., 2007; Humbert et al., 2010; 
Okello et al., 2010), models relating MCs and cyanobacterial abundances cannot be considered of general use outside the lakes where they were defined. On the other side, the estimation of MCs based on lake-tailored models could increase the sensitivity and reliability of management options compared with approaches based on fixed abundance levels irrespective of the species types or selected cyanotoxins-producing genotypes.

\section{Conclusion}

The study of the dominant cyanobacteria ( $P$. rubescens) in two nearby and connected lakes with different physiographic and environmental characteristics (Garda and Ledro) provided the opportunity to evaluate the hypothesis that the two populations had the same ability to produce MCs. In each lake, the Bayesian analyses linking the microcystin concentrations and the biovolumes of Planktothrix did not show differences along the water column. Moreover, models linking $\mathrm{MCs}$ and $\mathrm{BV}_{\mathrm{Pr}}$ were similar in the two lakes, irrespective of the differences in the physiographic characteristics and trophic state. Overall, these results suggest a constitutive microcystin production relatively independent from environmental factors, and the existence of two similar strains inhabiting the two lakes favoured by the lack of spatial isolation. It was stressed how the use of specific lake-tailored models linking $\mathrm{MCs}$ and $\mathrm{BV}_{\mathrm{Pr}}$ could provide a greater sensitivity and reliability in the definition of the management strategies aimed at minimizing the risks due to cyanobacteria development.

Acknowledgements. This study was financed by the EU Central Europe Programme (Project EULAKES, 2CE243P3) and the Autonomous Province of Trento (Project ACE-SAP, University and Scientific Research Service; Projects Ledro I-II, Servizio Valutazione Ambientale). The investigations were made in the framework of the LTER (Long-Term Ecological Research) Italian network, site "Southern Alpine lakes", IT08-000-A (http://www.lteritalia.it/). The activity was also supported by a PhD fellowship to S.S. from the IASMA Research and Innovation Centre, E. Mach Foundation. We thank the European Cooperation in Science and Technology COST Action ES1105 CYANOCOST for networking and knowledgetransfer support. We are grateful to the technical staff of the Hydrochemistry technological platform of the IASMA Research and Innovation Centre (FEM-IASMA) for their support in the field and laboratory activities.

\section{References}

Akcaalan R., Young F.M., Metcalf J.S., Morrison L.F., Albay M. and Codd G.A., 2006. Microcystin analysis in single filaments of Planktothrix spp. in laboratory cultures and environmental blooms. Water Res., 40, 1583-1590.

Almodóvar A., Nicola G.G. and Nuevo M., 2004. Effects of a bloom of Planktothrix rubescens on the fish community of a Spanish reservoir. Limnetica, 23, 167-178.
Anneville O., Gammeter S. and Straile D., 2005. Phosphorus decrease and climate variability: mediators of synchrony in phytoplankton changes among European peri-alpine lakes. Freshw. Biol., 50, 1731-1746.

APHA, AWWA and WEF, 2000. Standard Methods for the Examination of Water and Wastewater (19th edn), American Public Health Association, Washington.

Azevedo S.M.F., Carmichael W.W., Jochimsen E.M., Rinehart K.L., Lau S., Shaw G.R. and Eaglesham G.K., 2002. Human intoxication by microcystins during renal dialysis treatment in Caruaru-Brazil. Toxicology, 182, 441-446.

Bogialli S., Nigro Di Gregorio F., Lucentini L., Ferretti E., Ottaviani M., Ungaro N., Abis P.P. and Cannarozzi De Grazia M., 2013. Management of a toxic cyanobacterium bloom (Planktothrix rubescens) affecting an Italian drinking water basin: a case study. Environ. Sci. Technol., 47, 574-583.

Buzzi F., 2002. Phytoplankton assemblages in two sub-basins of Lake Como. J. Limnol., 61, 117-128.

Carraro E., Guyennon N., Hamilton D., Valsecchi L., Manfredi E.C., Viviano G., Salerno F., Tartari G. and Copetti D., 2012. Coupling high-resolution measurements to a three-dimensional lake model to assess the spatial and temporal dynamics of the cyanobacterium Planktothrix rubescens in a medium-sized lake. Hydrobiologia, 698, 77-95.

Cerasino L. and Salmaso N., 2012. Diversity and distribution of cyanobacterial toxins in the Italian subalpine lacustrine district. Oceanol. Hydrobiol. St., 41, 54-63.

Chorus I., 2012. Current Approaches to Cyanotoxin Risk Assessment, Risk Management and Regulations in Different Countries, Federal Environment Agency (Umweltbundesamt), Dessau-Roßlau, Germany, 147, Available online at: http://www.uba.de/uba-info-medien-e/ 4390.html.

D'alelio D., Gandolfi A., Boscaini A., Flaim G., Tolotti M. and Salmaso N., 2011. Planktothrix populations in subalpine lakes: selection for strains with strong gas vesicles as a function of lake depth, morphometry and circulation. Freshwat. Biol., 56, 1481-1493.

de los Ríos A., Ascaso C., Wierzchos J., Fernández-Valiente E. and Quesada A., 2004. Microstructural characterization of cyanobacterial mats from the McMurdo Ice Shelf, Antarctica. Appl. Environ. Microbiol., 70, 569-580.

Dietrich D. and Hoeger S., 2005. Guidance values for microcystins in water and cyanobacterial supplement products (blue-green algal supplements): a reasonable or misguided approach? Toxicol. Appl. Pharm., 203, 273-289.

Dokulil M.T. and Teubner K., 2012. Deep living Planktothrix rubescens modulated by environmental constraints and climate forcing. Hydrobiologia, 698, 29-46.

Ellison A.M., 2004. Bayesian inference in ecology. Ecol. Lett., 7, 509-520.

Fleming L.E., Rivero C., Burns J., William C., Bean J.A., Shea K.A. and Stinn J., 2002. Blue green algae (cyanobacterial) toxins, surface drinking water, and liver cancer in Florida. Harmful Algae, 1, 57-168.

Gallina N., Anneville O. and Beniston M., 2011. Impacts of extreme air temperatures on cyanobacteria in five deep periAlpine lakes. J. Limnol., 70, 186-196.

Gallina N., Salmaso N., Morabito G. and Beniston M., 2013. Phytoplankton configuration in six deep lakes in the periAlpine region: are the key drivers related to eutrophication and climate? Aquat. Ecol., 47, 177-193. 
Guzzella L., Ghislanzoni L., Pozzoni F., Cerasino L. and Salmaso N., 2010. Determinazione di tossine algali (microcistine e nodularina) nelle acque superficiali. Notiziario dei metodi analitici, IRS-CNR, 1, 17-31.

Hobbs N.T. and Hilborn R., 2006. Alternatives to statistical hypothesis testing in ecology: a guide to self teaching. Ecol. Appl., 16, 5-19.

Hudnell H.K. (ed.), 2008. Cyanobacterial Harmful Algal Blooms: State of the Science and Research Needs, Springer, NY, USA, 949.

Humbert J.F., Quiblier C. and Gugger M., 2010. Molecular approaches for monitoring potentially toxic marine and freshwater phytoplankton species. Anal. Bioanal. Chem., 397, 1723-1732.

Humpage A.R., 2008. Toxin types, toxicokinetics and toxicodynamics. Adv. Exp. Med. Biol., 619, 383-415.

Jacquet S., Briand J.-F., Leboulanger C., Avois-Jacquet C., Oberhaus L., Tassin B., Vinçon-Leite B., Paolini G., Druart J.-C., Anneville O. and Humbert J.-F., 2005. The proliferation of the toxic cyanobacterium Planktothrix rubescens following restoration of the largest natural French lake (Lac du Bourget). Harmful Algae, 4, 651-672.

Kardinaal W.E.A. and Visser P.M., 2005. Dynamics of cyanobacterial toxins. Sources of variability in microcystin concentrations. In: Huisman J., Matthijs H.C.P. and Visser P.M. (eds.), Harmful Cyanobacteria, Springer, Dordrecht, 41-63.

Kass R.E. and Raftery A.E., 1995. Bayes Factors. J. Am. Stat. Assoc., 90, 773-795.

Kéry M., 2010. Introduction to WinBUGS for Ecologists. A Bayesian Approach to Regression, ANOVA, Mixed Models and Related Analyses, Academic Press - Elsevier, Burlington, MA, USA, 302.

Kristiansen J., 1996. Dispersal of freshwater algae - a review. Hydrobiologia, 336, 151-157.

Kurmayer R. and Gumperberger M., 2006. Diversity of microcystin genotypes among populations of the filamentous cyanobacteria Planktothrix rubescens and Planktothrix agardhii. Mol. Ecol., 15, 3849-3861.

Kurmayer R., Schober E., Tonk L., Visser P.M. and Christiansen G., 2011. Spatial divergence in the proportions of genes encoding toxic peptide synthesis among populations of the cyanobacterium Planktothrix in European lakes. FEMS Microbiol. Lett., 317, 127-37.

Lunn D.J., Thomas A., Best N. and Spiegelhalter D., 2000. WinBUGS - a Bayesian modelling framework: concepts, structure, and extensibility. Stat. Comput., 10, 325-337.

Lyck S., 2004. Simultaneous changes in cell quotas of microcystin, chlorophyll a, protein and carbohydrate during different growth phases of a batch culture experiment with Microcystis aeruginosa. J. Plankton. Res., 26, 727-736.

Martin A.D., Quinn K.M. and Park J.H., 2011. MCMCpack: Markov Chain Monte Carlo in R. J. Stat. Soft., 42, 1-21.

McCarthy M.A., 2007. Bayesian Methods for Ecology, Cambridge University Press, Cambridge, 296.

McCarthy M.A. and Masters P., 2005. Profiting from prior information in Bayesian analyses of ecological data. J. Appl. Ecol., 42, 1012-1019.

Meriluoto J. and Codd G.A. (eds.), 2005. TOXIC Cyanobacterial monitoring and cyanotoxin analysis. Acta Acad. Aboensis B, 65, 149.
Messineo V., Mattei D., Melchiorre S., Salvatorea G., Bogialli S., Salzano R., Mazza R., Capelli G. and Bruno M., 2006. Microcystin diversity in a Planktothrix rubescens population from Lake Albano (Central Italy). Toxicon, 48, 160-174.

Metcalf J.S. and Codd G.A., 2012. Cyanotoxins. In: Whitton B.A. (ed.), Ecology of Cyanobacteria II, Springer, Dordrecht, 651-675.

Metcalf J.S., Richer R., Cox P.A. and Codd G.A., 2012. Cyanotoxins in desert environments may present a risk to human health. Sci. Total Environ., 421-422, 118-123.

Morabito G., Ruggiu D. and Panzani P., 2002. Recent dynamics (1995-1999) of the phytoplankton assemblages in Lago Maggiore as a basic tool for defining association patterns in the Italian deep lakes. J. Limnol., 61, 129-145.

Naselli-Flores L. and Barone R., 2000. Phytoplankton dynamics and structure: a comparative analysis in natural and manmade water bodies of different trophic state. Hydrobiologia, 438, 65-74.

Naselli-Flores L., Barone R., Chorus I. and Kurmayer R., 2007. Toxic cyanobacterial blooms in reservoirs under a semiarid mediterranean climate: the magnification of a problem. Environ. Toxicol., 22, 399-404.

Nehring S., 1998. Non-indigenous phytoplankton species in the North-Sea: supposed region of origin and possible transport vector. Arch. Fish. Mar. Res., 46, 181-194.

Neilan B.A., Pearson L.A., Muenchhoff J., Moffitt M.C. and Dittmann E., 2012. Environmental conditions that influence toxin biosynthesis in cyanobacteria. Environ. Microbiol., 15, 1239-1253.

Nürnberg G.K., LaZerte B.D. and Olding D.D., 2003. An artificially induced Planktothrix rubescens surface bloom in a small kettle lake in Southern Ontario compared to blooms world-wide. Lake Reserv. Manag., 19, 307-322.

Okello W., Ostermaier V., Portmann C., Gademann K. and Kurmayer R., 2010. Spatial isolation favours the divergence in microcystin net production by Microcystis in Ugandan freshwater lakes. Water Res., 44, 2803-2814.

Paerl H., 2008. Nutrient and other environmental controls of harmful cyanobacterial blooms along the freshwater-marine continuum. In: Hudnell H.K. (ed.), Cyanobacterial Harmful Algal Blooms: State of the Science and Research Needs, Springer, New York, 217-237.

Paulino S., Valério E., Faria N., Fastner J., Welker M., Tenreiro R. and Pereira P., 2009. Detection of Planktothrix rubescens (Cyanobacteria) associated with microcystin production in a freshwater reservoir. Hydrobiologia, 621, 207-211.

Peretyatko A., Teissier S., De Backer S. and Triest L., 2010. Assessment of the risk of cyanobacterial bloom occurrence in urban ponds: probabilistic approach. Ann. Limnol. - Int. J. Lim., 46, 121-133.

R Core Team, 2013. R: A Language and Environment for Statistical Computing, R Foundation for Statistical Computing, Vienna, Austria. Available online at: http:// www.R-project.org/.

Reynolds C.S., 2006. The Ecology of Phytoplankton, Cambridge University Press, Cambridge, 535.

Rott E., Salmaso N. and Hoehn E., 2007. Quality control of Utermöhl based phytoplankton biovolume estimates - an easy task or a Gordian knot? Hydrobiologia, 578, 141-146. 
Salmaso N., 2002. Ecological patterns of phytoplankton assemblages in Lake Garda: seasonal, spatial and historical features. J. Limnol., 61, 95-115.

Salmaso N., 2011. Interactions between nutrient availability and climatic fluctuations as determinants of the long term phytoplankton community changes in Lake Garda, Northern Italy. Hydrobiologia, 660, 59-68.

Salmaso N., Buzzi F., Garibaldi L., Morabito G. and Simona M., 2012a. Effects of nutrient availability and temperature on phytoplankton development: a case study from large lakes south of the Alps. Aquat. Sci., 74, 555-570.

Salmaso N., Naselli-Flores L. and Padisák J., 2012b. Impairing the largest and most productive forest on our planet: how do human activities impact phytoplankton? Hydrobiologia, 698, $375-384$.

Sedmak B., Eleršek T., Grach-Pogrebinsky O., Carmeli S., Sever N. and Lah T.T., 2008. Ecotoxicologically relevant cyclic peptides from cyanobacterial bloom (Planktothrix rubescens) - a threat to human and environmental health. Radiol. Oncol., 42, 102-113.

Sivonen K. and Börner T., 2008. Bioactive compounds produced by cyanobacteria. In: Herrero, A. and Flores E. (eds.), The Cyanobacteria. Molecular Biology, Genomics and Evolution, Caister Academic Press, Norfolk, UK, $159-197$.

Sivonen K. and Jones G.J., 1999. Cyanobacterial toxins. In: Chorus I. and Bartram J. (eds.), Toxic Cyanobacteria in Water: A Guide to their Public Health Consequences, Monitoring and Management, Spon, London, UK, 41-111.

Sturtz S., Ligges U. and Gelman A., 2005. R2WinBUGS: a package for running WinBUGS from R. J. Stat. Softw., $12,1-16$.
Svircev Z., Krstic S., Miladinov-Milkov M., Baltic V. and Vldovic M., 2009. Freshwater cyanobacterial blooms and primary liver cancer epidemiological studies in Serbia. J. Environ. Sci. Heal. C, 27, 36-55.

Ueno Y., Nagata S., Tsutsumi T., Hasegawa A., Watanabe M.F., Park H.D., Chen G.C., Chen G. and Yu S.Z., 1996. Detection of microcystins, a blue-green algal hepatotoxin, in drinking water sampled in Haimen and Fusui, endemic areas of primary liver cancer in China, by highly sensitive immunoassay. Carcinogenesis, 17, 13171321.

Valério E., Faria N., Paulino S. and Pereira P., 2008. Seasonal variation of phytoplankton and cyanobacteria composition and associated microcystins in six Portuguese freshwater reservoirs. Ann. Limnol. - Int. J. Lim., 44, 189-196.

Walsby A.E. and Schanz F., 2002. Light-dependent growth rate determines changes in the population of Planktothrix rubescens over the annual cycle in Lake Zürich, Switzerland. New Phytol., 154, 671-687.

WHO, World Health Organization, 2008. Guidelines for Drinking-water Quality (3rd edn,), incorporating the first and second addenda. Volume 1 Recommendations. WHO, Geneva, 515.

Yéprémian C., Gugger M.F., Briand E., Catherine A., Berger C., Quiblier C. and Bernard C., 2007. Microcystin ecotypes in a perennial Planktothrix agardhii bloom. Water Res., 41, 4446-4456.

Yu S.Z., 1989. Drinking water and primary liver cancer. In: Tang Z.Y., Wu M.C. and Xia, S.S. (eds.), Primary Liver Cancer, Springer, Berlin, 30-37.

Zhou L., Yu H. and Chen K., 2002. Relationship between microcystin in drinking water and colorectal cancer. Biomed. Env. Sci., 15, 166-171. 